\title{
Smart citizens for smart cities: participating in the future
}

1 Richard Bull BA (Hons), MA, MBA, PhD Associate Head of School, Institute of Energy \& Sustainable Development, De Montfort University, Leicester, UK (corresponding author: rbull@dmu.ac.uk)
2 Marouane Azennoud MENg, MSC Smart City Programme Manager, Northamptonshire County Council, Northampton, UK
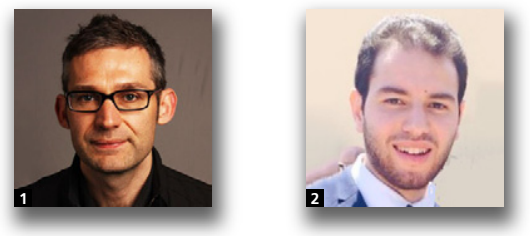

This paper discusses smart cities and raises critical questions about the faith being placed in technology to reduce carbon dioxide emissions. Given increasingly challenging carbon reduction targets, the role of information and communication technology and the digital economy are increasingly championed as offering potential to contribute to meeting these targets within cities and buildings. This paper questions the faith being placed in smart or intelligent solutions through asking, what role then for the ordinary citizen? The smart approach often appears to have a narrow view of how technology and user-engagement can sit together, viewing the behaviour of users as a hurdle to overcome rather than a resource to be utilised. This paper suggests lessons can be learnt from other disciplines and wider sustainable development policy that champions the role of citizens and user-engagement to harness the co-creation of knowledge, collaboration and empowerment. Specifically, empirical findings and observations are presented from a case study of citizen engagement around an energy-from-waste infrastructure development. Recommendations are provided for engineers, planners and decision makers in order to help plan more effective engagement strategies for citizens, building users and stakeholders.

Sicinius. What is the city but the people?

Citizens. True, the people are the city.

Coriolanus Act III, Scene I. William Shakespeare

\section{Introduction}

A significant cultural shift occurred recently with the majority of the world's population now living in cities and contributing more than two-thirds of global carbon dioxide emissions (UNEP, 2015). If countries such as the UK are to meet their challenging carbon reduction targets $-80 \%$ by 2050 for the UK - then how our cities are governed and managed to maximise energy efficiency is of vital importance. Faith is increasingly being placed in what are commonly referred to as 'smart cities' to meet these targets. Although most visions of these smart cities revolve around increased information and communication technology (ICT) efficiency through what has become known as the 'digital economy', smart cities seemingly offer a utopian vision of urban integration, efficiency and (subsequent) carbon reductions. However, is 'smart' purely seeking maximum technical efficiencies or does 'smart' need to incorporate citizens as well? Cities, the authors argue (in borrowing a well-cited phrase from Janda (2011)), like any building development or infrastructure, do not use energy, people do.

This paper first explores definitions of smart cities, before presenting a case study of citizen engagement around planning for sustainable waste management infrastructure that provides insight into how citizens can be engaged in smart city initiatives. The authors argue that the lessons learnt from this case are highly relevant for engaging citizens in infrastructure and engineering developments such as smart cities. Partnership working is not easy though, and in conclusion this paper offers reflections and practical recommendations for engaging citizens in cities more effectively.

\section{Smart cities - a review of definitions and concepts}

According to the Smart 2020 report Enabling the Low Carbon Economy in the Information Age, this new digital economy 


\section{Offprint provided courtesy of www.icevirtuallibrary.com Author copy for personal use, not for distribution}

could deliver $\sim 7 \cdot 8 \mathrm{GtCO}_{2 \mathrm{e}}$ of emissions savings by 2020 as a result of smart logistics, grids and buildings (SMART2020, 2008). With regard to buildings, for example, the report proclaims, 'better building design, management and automation could save $15 \%$ of North America's building emissions' (SMART2020, 2008: p. 9). In buildings, these automated systems vary in capability, but they afford energy managers the opportunity to control everything from the heating, ventilation and air conditioning systems to lighting controls and security systems without the ordinary building user having to do anything. Depending on the scale and complexity of the local controls, building users no longer have to worry about opening windows if it is too hot, switching on a light if it is too dark; the centrally controlled building energy management system (BEMS) takes care of everything. The question remains, though, whether this is a vision shared by those using these buildings or living in these new smart cities?

A smart or 'intelligent' approach to buildings, transport and cities can appear to imply or suggest the behaviour of the people is a hurdle to be overcome rather than a resource to be utilised. However, a wider literature review - for example, of the risk communication literature - shows that expert-led, topdown technocentric solutions rarely deliver on their promises (Fiorino, 1990; Leach et al., 2010; Renn, 1992). Staying with buildings for a moment, user experience and the literature indicate that around $30 \%$ of energy in buildings is wasted through the behaviour of the building users (Brown et al., 2012). Such waste is in part due to the technical limitations and flaws inherent within BEMS, such as the reliability of sensors, the quality of algorithms alongside human error.

The phrase 'smart city' has emerged during the last decade and has been used, since then, by different companies but notably the information technology (IT) sector and companies such as Cisco (2014), IBM (http://www.ibm.com/smarterplanet/us/en/ smarter_cities/overview/) and Siemens (http://w3.siemens.com/ topics/global/en/sustainable-cities/Documents/smart-cities-en/ index.html\#/en/home). However, according to Harrison and Donnelly (2011), this concept is not new; its origins go back to the smart growth movement in the late 1990s. Definitions of smart cities vary according to the sector in which they are used and it is immediately evident from the range of definitions that there is little consensus. In the next section, the views of industry and policymakers are briefly reviewed before looking at an example of smart participation.

\subsection{Industry definitions}

Many companies, mainly from the IT industry, are providing their visions and interpretations of the concept of the smart city. Businesses like Cisco (2014), IBM, Schneider Electric (http://www2.schneider-electric.com/sites/corporate/en/solutions/ sustainable_solutions/smart-cities.page) and Siemens are using this concept to market their vision for the cities of tomorrow through the 'application of complex information systems to integrate the operation of urban infrastructure and services such as buildings, transportation, electrical and water distribution, and public safety' (Paroutis et al., 2014: p. 2). Therefore, these companies appear more focused on using information systems to solve the problems facing cities. Table 1 highlights some of the key features and differences of these organisations' vision of smart cities.

They highlight the efficiencies to be gained through greater technical integration of public services - energy, transport, street lighting and so on. These integrations and efficiencies are of course to be welcomed but yet offer a one-dimensional view of the smart city.

\subsection{Policymakers}

Smart cities have become a major policy initiative of the European Union. In their strategic implementation plan for 'smart cities and communities' (EC, 2013: p. 5), they define smart cities as

... systems of people interacting with and using flows of energy, materials, services and financing to catalyse sustainable economic development, resilience, and high quality of life; these flows and interactions become smart through making strategic use of information and communication infrastructure and services in a process of transparent urban planning and management that is responsive to the social and economic needs of society.

In this document, they describe areas of focus around sustainable urban mobility, energy-efficient buildings and integrated infrastructures and processes across energy, ICT and transport. Space is given to the need for increased citizen engagement and the benefits that it brings. The areas of focus are $(a)$ developing a common European framework for cities, $(b)$ removing barriers from experimental initiatives that innovate, increase knowledge and support co-creation, and (c) establishing local citizens committees to work with local public authorities, small and mediumsized enterprises (SMEs) and larger industry in order to set the targets for developments.

Here in the UK, the Department for Business, Innovation and Skills (BIS) has defined the process by which cities turn into smart ones rather than trying to define the concept. It refers to the process as one in which cities become more liveable and resilient'. For BIS, a smart city should enable every citizen to engage with all the services on offer, public as well as private, in a way best suited to his or her needs and incorporates 'hard infrastructure, social capital including local skills and community institutions, and (digital) technologies to fuel sustainable economic development and provide an attractive environment for all'. (BIS, 2013: p. 7). 


\begin{tabular}{ll} 
Company & \multicolumn{1}{c}{ Vision } \\
\hline IBM & $\begin{array}{c}\text { Cities can capitalise on new technologies and insights } \\
\text { to transform their systems, operations and service } \\
\text { delivery. Being smarter can change the way their } \\
\text { cities work and help deliver on their potential as } \\
\text { never before }\end{array}$ \\
Schneider & $\begin{array}{l}\text { Cities need to become smarter, more efficient, } \\
\text { Electric }\end{array}$ \\
& $\begin{array}{l}\text { sustainable and liveable. This can be done through } \\
\text { collaboration with different entities (municipality, } \\
\text { council etc.) to deliver urban efficiency }\end{array}$
\end{tabular}

Siemens Smart cities should find ways to optimise their infrastructure through intelligent infrastructure solutions - such as smart grids, building automation, security solutions and traffic control systems

Cisco Smart cities should include an integrated urban ICT that can overlay on a city and can support delivery of connected urban services and allow for efficient management of those services on a global scale
Key features

- Big data and analytics for deeper insights

- The 'cloud' for collaboration among disparate agencies, mobile to gather data and address problems directly at the source, social technologies for better engagement with citizens

- Smart energy: energy management system to make end users, renewable energy sources and electric vehicles efficient and smartly connected to the grid

- Smart water: use of management systems to detect water leaks in the network, to optimise the energy used for supplying water, and to provide solutions to face storms and floods

- Smart building: use of building management systems to monitor the energy use

- Smart mobility: traffic and transit management systems that deliver real-time visibility across the entire transportation network, electric vehicles and efficient and safe recharging infrastructure by way of tolling and congestion charging solutions

- Smart public services: solutions ranging from street lighting to the public safety with a focus on data collection for better management

- Smart integration: linking different management systems available in the city to increase the efficiency of each one of them and the overall efficiency of the city

- The use of sensors, communications, computational ability and control in some form to enhance the overall functionality of the electric power delivery system

- Leveraging the 'Internet of Everything', cities can integrate people, processes, data and things to create safe and vital places to live, work, learn and play

Table 1. Overview of organisations' vision of smart cities

Hence, while companies may be adopting a more technocentric view of smart cities, policymakers are hoping to see the citizen as an essential stakeholder.

\subsection{Reflections}

This lack of clarity is reflected in the wider academic literature on smart cities. A recent study (De Jong et al., 2015) highlighted 12 different categories of cities in the literature for the period running from 1996 to 2013: 'sustainable city', 'eco-city', 'lowcarbon city', 'liveable city', 'green city', 'smart city', 'digital city', 'ubiquitous city', 'intelligent city', 'information city', 'knowledge city' and 'resilient city'. They found 'sustainable city' had the highest number of occurrences followed by 'smart city'. However, the importance of this study resides in defining the links between these different types depending on their number of occurrences in the selected range of academic literature.

It can be seen from Figure 1 that 'smart city' is linked more to 'digital city', 'intelligent city', 'eco-city' and 'low-carbon city'. 'Low-carbon city' is viewed as a subset of sustainable city, whereas smart city is viewed as a new concept with particular connotations around integrated building and technological fixes. Huber and Mayer (2015) agree that there is no clear definition or conceptual content of smart cities, unlike the lowcarbon and eco-cities, and that it is still a fuzzy concept; 




Figure 1. Links between the 12 different types of cities (De Jong

et al., 2015: p. 30)

but there exists many interpretations. They conceptualise this through three perspectives as follows.

(a) Instrumental perspective. This consists of using ICT to gather high-quality data from different sources of information in shorter times to help improve the work of institutions, such as municipalities, through the processing of these data in order to produce meaningful information which can help in building the right strategies and making decisions.

(b) Administrative perspective. The goal of a smart city is to unify the work of institutions through the establishment of a smart policy. In other words, it is fundamental for all structures/departments belonging to the same municipality, as an example, to interact and unify their efforts to develop a vision for the city; a vision that has as a starting point defining the needs of the citizens and as an endpoint meeting those needs.

(c) Governance perspective. Citizens should have a great role in defining how their cities should look, this is why it is essential to overcome the traditional top-down governance and transit to a new governance style; a style that enables integration of all stakeholders in the decision making.

This governance perspective gets to the core issue of how citizens are engaged in decision making, be it for the design of a new building, infrastructure project or city-level planning such as a new transport policy or carbon management strategy. What does it mean actually to engage the citizens of a particular area or city? Before presenting a concrete example, the theoretical framework around public participation is briefly discussed.

\section{Smart citizens?}

The principles of public participation methods have been tried and tested in the siting of controversial facilities such as waste facilities (Bull et al., 2008) and transport planning (Bickerstaff and Walker, 2005). Sovacool (2014) notes three benefits of engaging 'non-experts': first, democracy is increased as all citizens have a right to participate and be represented in environmental decision making; second, non-experts are often more attuned to the ethical issues of a situation; and third, greater acceptance can often be achieved by involving those affected by the situation. Most relevant to this subject is the strong and emerging links between public engagement and learning, increased environmental citizenship and behaviour change (Bull et al., 2008). As Webler et al. (1995) discovered in their research into this field

When citizens become involved in working out a mutually acceptable solution to a project or problem that affects their community and their personal lives, they mature into responsible 


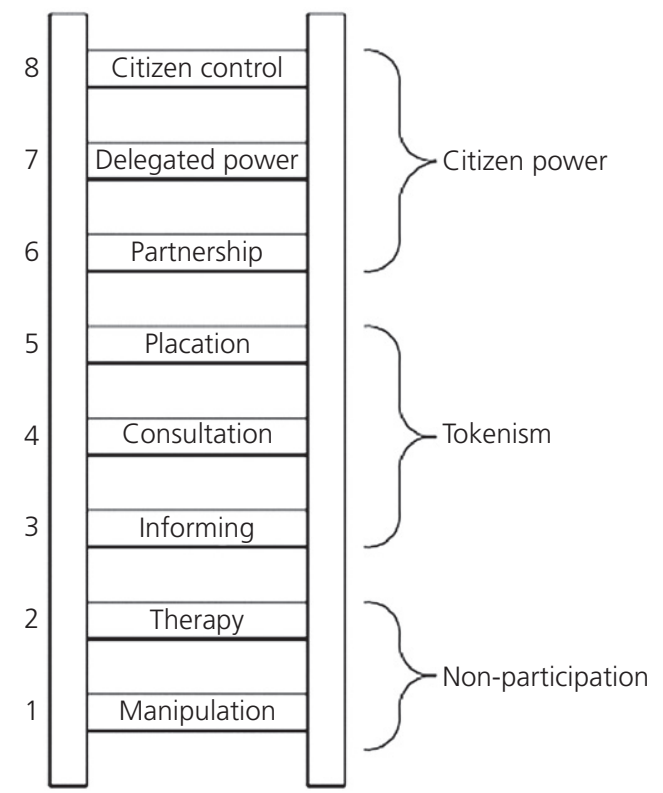

Figure 2. Arnstein's ladder of participation

democratic citizens and reaffirm democracy (Webler et al., 1995: p. 444)

Back in 1969, Arnstein's (1969) 'ladder of participation' (Figure 2) defined steps to better engagement. At the bottom was information provision, a predominantly one-way form of communication; moving up the steps, consultation is usually conceived as a relatively passive process asking for people's opinions but not necessarily engaging them in debate. Participation is normally used to refer to processes which allow people to participate in a decision by putting forward their views verbally, whereas engagement goes further, suggesting an innovative and interactive two-way process of discussion and dialogue (i.e. deliberation) to ensure that people's views inform a decision, alongside those of the expert and/or the decision maker. This is still one step removed, however, from Arnstein's top step of her ladder that defines empowerment as people taking control of decisions and their implementation.

The theoretical underpinnings find their roots in Habermas' theory of communicative competence (Habermas, 1979) which was successfully mined in the early 1990s by Thomas Webler (1995). Webler (1995) explored how language functions to form the key foundational principles for the management of deliberative practices within the school of risk communication. Working from the premise that participation is 'interaction among individuals through the medium of language' (Webler, 1995: p. 40), Habermas (1979) argues that any communication between two individuals would fail without co-operation. An individual's ability to use language to create understanding and consensus is referred to as 'communicative competence'. Habermas (1979) outlined a set of ideal conditions in which communicative competence would be best served, known as his 'ideal speech situation'. Webler (1995) applied these principles of communication to the formulation of a set of criteria and rules that would transform democratic ideals of deliberative democracy into practice.

In short, people can be a valuable source of knowledge and wisdom and, if given the opportunity, are capable of handling complex information and resolving complex problems. Yet, these principles are still under-researched with regard to engaging citizens in the context of smart cities and questions remain as to how applicable they are. These questions are to be explored, but first, the case study is introduced.

\section{An example of smart citizen engagement}

So what does this actually look like in practice, and what relevance has this for smart cities? As outlined earlier, the EU smart cities and communities agenda is seeking exemplars of citizen engagement yet often the concepts are lacking focus or application. This example from the 1990s provides a clear demonstration of what is possible. In the early 1990s, Hampshire was facing a waste crisis. Landfill capacity was rapidly decreasing (limited by the permeable geology of the county), higher regulatory standards were too demanding for the five existing incinerators and increasing waste quantities were placing an excessive burden on the existing infrastructure (Petts, 1995). In 1992, under contract to Hampshire County Council (HCC), the waste contractor failed in submitting a planning application for a $400000 \mathrm{t}$ per annum energy-from-waste (EfW) plant to handle municipal waste. The county went back to the drawing board and decided to try a different approach. Decisions were made to engage the public in a discussion of an appropriate waste strategy to manage household waste in Hampshire. A highly innovative engagement process based on deliberative ideals was designed, with three community advisory fora (CAFs) across the county at the centre of the communication strategy. The CAFs were facilitated and administered by a team of engagement consultants knowledgeable in waste management, and were independently chaired.

Composed of 16-20 people from diverse backgrounds with broad interests, their purpose was to receive and debate information about Hampshire's waste problem, to discuss the available options and to submit a report to the county detailing their preferred option. Each CAF met six times on a monthly basis; beginning with an explanation of the process and the background to the waste strategy, the meetings progressed to consider the available options for dealing with the waste crisis. Views were sought on how to implement the waste hierarchy (reduce, reuse, recycle, dispose) in the context of Hampshire. The process encouraged debate and opportunities to challenge and validate claims through small-group and plenary discussions. 


\section{Offprint provided courtesy of www.icevirtuallibrary.com Author copy for personal use, not for distribution}

The outcome was an agreed waste strategy which was put out to tender. Onyx (now Veolia Environmental Services) won the contract and formed a novel partnership with the county (operating as Hampshire Waste Services (HWS) under the title Project Integra) to deliver three new, small (under $200000 \mathrm{t}$ per annum) EfW plants. Part of their contract required them to engage with each local community prior to submitting the planning applications. To that end three contact groups were convened by HWS to discuss the developing applications and associated environmental impact assessments. They recruited people on a basis similar to that used for the CAFs, but this time from the directly potentially affected communities. For HWS using this 'contact group' process was a key milestone. Two of the three facilities were granted planning permission without having to go to public inquiry, with evidence of political confidence to take a local decision.

Figure 3 is developed from an analysis of the structures that exist to manage waste in Hampshire and provides a model of engagement for smart cities. Local authorities, business and individual citizens all worked together in different ways to confront the problem of sustainable waste management. With the goal of learning in the centre, a framework is presented to illustrate the context, influences and relationships necessary for learning.

Learning is at the centre of the framework in Figure 3. This is not to imply that learning occurs abstractly, separate from the actors or the processes. Rather learning is located centrally to illustrate the external influences on the process. The arrows suggest these influences, but also stress the two-way responsive effects of the learning process. The case studies clearly show that not only did the actors influence the learning process but the process also influenced them. Crucially, removing any side of the triangle will negatively affect the potential for learning. The findings of this research suggest that optimal (social and

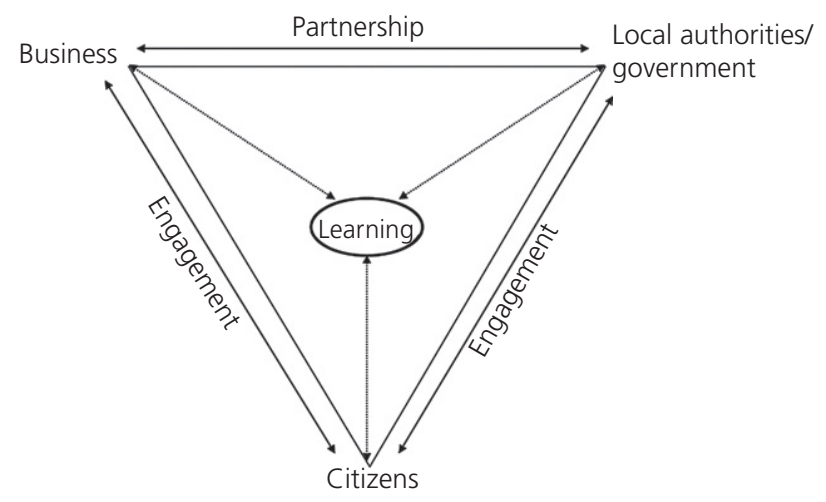

Figure 3. A relational framework for learning organisational) learning and effective public engagement are both interlinked and dependent on effective relationships between all three of the actors involved in the waste management cycle.

To conceptualise this learning several established models have been used. Jack Mezirow's (1994, 2003) transformative learning theories helped an understanding of the beyond-process learning of the CAF members in Hampshire. Like many theories around learning through engagement or discourse, Mezirow (1994, 2003) focuses on the conditions within the learning environment essential to understanding how to design and manage engagement processes to best enhance learning. Mezirow (2003) speaks of actively managing the process to maximise learning, and other empirical evidence has identified the required components of management (Petts, 2006).

Partnership was central to the waste management sector and crucial if cities are to become truly smart. Davoudi and Evans (2005) have drawn attention to the effects of the restructuring of society and the role of the state in mediating power through devolving responsibilities to regional agencies and partnerships. Slater et al. (2007) contrast partnership with a technocratic client-contractor approach, characterised by long-term contracts with one service provider operating large, centralised facilities. Long-term private-finance-initiative (PFI) types of contracts are typically associated with this approach. Project Integra was a PFI-type contract within which the role of the private waste contractor, HWS, was central. Slater et al. (2007) highlight three ingredients of successful partnerships: emotional commitment, agreed shared vision and common objectives. In Project Integra, these have been exhibited and promoted particularly not only by the key individual champions but also by the participation and support of all 13 districts in the development of the household waste strategy and then its implementation.

Through these connections, successful implementation of the waste strategy becomes the responsibility of everyone. In a partnership such as Project Integra, business and local authorities are mutually dependent on one another. In this way, partnership denotes a shared emotional commitment to work together, steered and managed by people with vision.

\section{Discussion}

Slater et al. (2007) argued that partnership working is capable of achievements that would not be feasible if individual partners worked in isolation. Those authors are referring to the technical benefits of partnership working between local authorities: for example, greater economies of scale concerning recycling collection initiatives and securing contracts for recyclables. This was the case in Hampshire where partnership 


\section{Offprint provided courtesy of www.icevirtuallibrary.com Author copy for personal use, not for distribution}

working with all of the local authorities enabled greater efficiencies and sharing of best practice.

Partnerships between business and local authorities provided mutual learning benefits. However, such partnerships have a sphere of influence beyond themselves. Project Integra provided clear, united governance, depoliticising the issue of waste - that is, the public viewed no single party as responsible. Instead, a neutral organisation was created. The partnership appeared to create a culture of trust, which enabled the public engagement to function more effectively and increased the opportunity for learning. This is significant given that so often the interests of business, under the influence of market forces, and local authorities implementing policy are viewed as competing with one another (Forester, 1985), and particularly important given the often contentious nature of infrastructure developments.

In Hampshire, the framework of Project Integra, and the consultation process that preceded the formation of the partnership, provided HWS with a confidence to develop the contact group process around the proposed sites for EfW plants. A household waste strategy informed by the CAF process meant that the broader issues surrounding waste management were dealt with and had achieved a consensus. HWS were now relatively free to engage with the specific issues and concerns surrounding EfW. As such, the contact group process was reasonably successful attendance was strong and the debates mainly lively and constructive. In one of the contact groups, interviewees reported not only a good experience, but also significant impact on the route of the waste lorries (to and from the facility) as well as the design of the facility (Bull et al., 2008, 2010).

The influence of the CAFs on the learning of the individuals involved, and as a precursor to effective facilitation of the contact group process, cannot be overstated. The decision taken by the HCC to use these groups and to involve the private sector in running and facilitating them was instrumental. It provided a degree of independence and, importantly, it brought highly professional and knowledgeable (in terms of waste management) facilitators into the process. The contact group process has the opportunity to bridge the missing link in the governance of waste between citizens and business. Veolia did not just stop their public engagement once a planning application had been submitted either. All of the three facilities in Hampshire have liaison groups that meet quarterly throughout the year. These operate on a basis similar to the contact group process, being made up of local people, some of whom were involved in the original process. They are independently chaired and exist to provide an ongoing interface between Veolia and the local community. For example, the Marchwood liaison group has been able to hold HWS to account on the agreed traffic routes, discuss screening arrangements and generally review the ongoing running and performance of the relatively new facility.
Using deliberative processes through the contact group model has the potential to benefit everyone, providing the vital link in the chain between business, local authorities and citizens.

\section{Conclusion and recommendations}

So what has this all to do with planning and developing smart city technologies, engineering and infrastructure? First, it is important to be clear what is being talked about with regard to smart cities, what is promised with regard to these developments and who is defining the terms of engagement for smart cities. Participatory processes like those outlined here provide a clear and tangible model of engagement for industry and local authorities for engaging citizens beyond the statutory public consultations that rarely go beyond 'information provision'. Crucially though, it also shows the benefits of engagement and should inspire decision makers to cease viewing stakeholder engagement as a 'box-ticking' exercise but rather a strategic decision to improve business process and quality of life for all.

Engagement then is more than providing information and feedback; genuine participation accesses the knowledge and skills of all the actors and stakeholders to provide greater legitimacy and improved processes.

Within this case study, five key recommendations can be found for organisations, individuals and decision makers wishing to develop engagement processes to develop 'smarter citizens'.

- Decide on an appropriate engagement strategy that is fit for purpose and clearly distinguishes between consultation and engagement (i.e. climbing higher up Arnstein's ladder - Figure 2) with a view to allowing all those affected by the decision to have a say in the outcome rather than be passive recipients of information.

- Identify suitable well-trained individuals to lead the process. Public engagement requires particular skills, notably related to empathy, excellent communication skills and diplomacy. Better not to undertake it at all than to do it badly.

- Allow sufficient time for the process. However, time invested upfront will pay dividends (depending on the intervention) in terms of more motivated staff, engaged citizens and genuine sharing of knowledge between all parties involved.

- Clearly communicate the impacts of the engagement on the decision-making process, being transparent and open throughout the whole process.

- Finally, do not underestimate the benefits of 'unplanned' and informal social times for interactions. Allow time for informal activities, invest in good quality refreshments and ensure everyone gets time to meet all those involved. 


\section{REFERENCES}

Arnstein S (1969). A ladder of citizen participation. Journal of the American Institute of Planners 35: 216-244.

Bickerstaff K and Walker G (2005) Shared visions, unholy alliances: power, governance and deliberative processes in local transport planning. Urban Studies 42(12): 2123-2144.

BIS (Department for Business, Innovation, and Skills) (2013) Smart Cities: Background Paper. BIS, London, UK. See https://www.gov.uk/government/uploads/system/ uploads/attachment_data/file/246019/bis-13-1209smart-cities-background-paper-digital.pdf (accessed 27/04/2015).

Brown N, Bull R, Farhuk F and Ekwevugbe, T (2012) Novel instrumentation for monitoring after-hours electricity consumption of electrical equipment, and some potential savings from a switch-off campaign. Energy and Buildings 47: 74-83.

Bull R, Petts J and Evans J (2008) Social learning from public engagement: dreaming the impossible? Journal of Environmental Planning and Management 51(5): 701-716.

Bull R, Petts J and Evans J (2010) The importance of context for effective public engagement. Journal of Environmental Planning and Management 53(8): 991-1009.

Cisco (2014) Cisco Smart + Connected Communities: Envisioning the Future of Cities Now. Cisco Systems, Inc., San Jose, CA, USA. See http://www.cisco.com/web/strategy/ docs/smart-cities-expo-barcelona.pdf (accessed 14/03/2015).

Davoudi S and Evans N (2005) The challenge of governance in regional waste planning. Environment and Planning $C$ 23(4): 493-517.

De Jong M, Joss S, Schraven D, Zhan C and Weijnen M (2015) Sustainable-smart-resilient-low carbon-eco-knowledge cities; making sense of a multitude of concepts promoting sustainable urbanization. Journal of Cleaner Production 109: 25-38.

EC (European Commission) (2013) European Innovation Partnership on Smart Cities and Communities: Strategic Implementation Plan. EC, Brussels, Belgium. See http://ec.europa.eu/eip/smartcities/files/sip_final_en.pdf (accessed 16/03/2015).

Fiorino DJ (1990) Citizen participation and environmental risk: a survey of institutional mechanisms. Science, Technology and Human Values 15(2): 226-243.

Forester J (1985) The policy analysis - critical theory affair: Wildavsky and Habermas as bedfellows? In Critical Theory and Public Life (Forester J (ed.)). MIT, London, UK, pp. $258-280$.

Habermas J (1979). Communication and the Evolution of Society, translated by Thomas McCarthy. Beacon Press, Boston, MA, USA.
Harrison C and Donnelly IA (2011) A theory of smart. Proceedings of the 55th Annual Meeting of the ISSS, Hull, $U K$, pp. 1-15. See http://journals.isss.org/index. php/proceedings55th/article/viewFile/1703/572 (accessed 01/03/2015).

Huber A and Mayer I (2015) Is this a smart city? Narratives of city smartness and their critical assessment. Proceedings of the 2015 ECEE Summer Study Conference, Club Belambra Les Criques, Presqu'île de Giens Toulon/Hyères, France, pp. 817-823.

Janda K (2011) Building's don't use energy: people do. Architectural Science Review 54(1): 15-22.

Leach M, Scoones I and Stirling A (2010) Dynamic Sustainabilities: Technology, Environment and Social Justice. Earthscan, London, UK.

Mezirow J (1994) Understanding transformation theory. Adult Education Quarterly 44(4): 222-232.

Mezirow J (2003) Transformative learning as discourse. Journal of Transformative Education 1(1): 58-63.

Paroutis S, Bennett MM and Heracleous L (2014) A strategic view on smart city technology: the case if IBM smarter cities during a recession. Technological Forecasting and Strategic Change 89: 262-272.

Petts J (1995) Waste management strategy development: a case study of community involvement and consensus-building in Hampshire. Journal of Environmental Planning and Management, 38(4): 519-536.

Petts J (2006) Managing public engagement to optimize learning: reflections from urban river restoration. Human Ecology Review 13(2): 172-181.

Renn O (1992) Risk communication: towards a rational discourse with the public. Journal of Hazardous Materials 29(3): 465-519.

Slater R, Frederickson J, Thomas C, Wield D and Potter S (2007). A critical evaluation of partnerships in municipal waste management in England. Resources, Conservation and Recycling, 51(3): 643-664.

SMART2020 (2008) Enabling the Low Carbon Economy in the Information Age. SMART2020, The Climate Group, London, UK. See http://www.smart2020.org/_assets/files/ 02_Smart2020Report.pdf (accessed 10/09/2015).

Sovacool B (2014) What are we doing here? Analyzing fifteen years of energy scholarship and proposing a social science research agenda. Energy Research and Social Science 1: 1-29.

UNEP (United Nations Environmental Programme) (2015) Cities and Buildings. UNEP-DTIE Sustainable Consumption and Production Branch, Paris, France. See http://www.unep.org/ SBCI/pdfs/Cities_and_Buildings-UNEP_DTIE_Initiatives_ and_projects_hd.pdf (accessed 01/10/2015).

Webler T (1995) 'Right' discourse in citizen participation: an evaluative yardstick. In Fairness and Competence in Citizen Participation: Evaluating Models for 
Environmental Discourse (Renn O, Webler T and Wiedemann P (eds)). Kluwer Academic Publishers, London, UK, pp. 35-86.
Webler T, Kastenholz H and Renn O (1995) Public participation in impact assessment: a social learning perspective. Environmental Impact Assessment Review 15(5): 443-463.
WHAT DO YOU THINK?

To discuss this paper, please email up to 500 words to the editor at journals@ice.org.uk. Your contribution will be forwarded to the author(s) for a reply and, if considered appropriate by the editorial panel, will be published as discussion in a future issue of the journal.

Proceedings journals rely entirely on contributions sent in by civil engineering professionals, academics and students. Papers should be 2000-5000 words long (briefing papers should be 1000-2000 words long), with adequate illustrations and references. You can submit your paper online via www.icevirtuallibrary.com/content/journals, where you will also find detailed author guidelines. 